\title{
100 years of scientific research and development of plant protection in Poland
}

\section{Part 1. Years 1918-1945}

\section{0 lat badań naukowych i rozwoju ochrony roślin w Polsce}

\section{Cz. I. Lata 1918-1945}

\author{
Stefan Pruszyński*
}

\section{Summary}

In 1918, after Poland regained its independence, a new research unit, Plant Protection Department was created at the Research Institute of Rural Husbandry in Puławy. It was the beginning of performing structured research, phytosanitary observations, controlling quarantine organisms, education to strengthen the next generations of scientist and producers, and establishing extension services to provide the knowledge to the agricultural workforce. Previously in the 18th and 19th century, scientists of Polish origin conducted research and developed plant protection on the farms, which were under Russian and Austrian partition. In the subsequent two manuscripts, the first for the years 1918-1945 and the second for the period after world war II to the present time, the history of plant protection in Poland and the contribution of Polish researchers to the development of this agricultural activity in Poland and in the world will be presented.

Key words: Poland, plant protection, history, development, current state

\section{Streszczenie}

W roku 1918 po odzyskaniu przez Polskę niepodległości, powołano w nowo utworzonym Instytucie Naukowym Gospodarstwa Wiejskiego w Puławach, Oddział Ochrony Roślin i był to początek prowadzenia zorganizowanych badań, nauczania, obserwacji fitosanitarnych, zwalczania organizmów kwarantannowych, tworzenia służby ochrony roślin i doradztwa w zakresie ochrony roślin w Polsce. Wcześniej, w XVIII i XIX wieku, uczeni polskiego pochodzenia prowadzili badania i rozwijali ochronę roślin na farmach będących pod rosyjskim i austriackim zaborem. W dwóch kolejnych opracowaniach, pierwszym obejmującym lata 1918-1945 i drugim za okres po II wojnie światowej do czasów obecnych, omówiona zostanie historia ochrony roślin w Polsce i wkładu polskich pracowników naukowych w rozwój tej działalności rolniczej w Polsce i na świecie.

Słowa kluczowe: Polska, ochrona roślin, historia, rozwój, stan obecny

Emerytowany profesor

Instytutu Ochrony Roślin - Państwowego Instytutu Badawczego

Władysława Węgorka 20, 60-318 Poznań

*corresponding author: marprusz1@tlen.pl 


\section{Wstęp / Introduction}

1 stycznia 1918 roku w Puławach w nowo utworzonym polskim Instytucie Naukowym Gospodarstwa Wiejskiego (INGW) rozpoczął działalność kierowany przez prof. Józefa Trzebińskiego, Dział Ochrony Roślin. Fakt ten należy uznać za początek zorganizowanych badań i działań praktycznych w ochronie roślin w Polsce.

W roku 2018 minęło zatem 100 lat od daty powołania Oddziału Ochrony Roślin i rok ten na równi z wieloma innymi wydarzeniami powinien być traktowany jako rok Jubileuszowy dla nauki i służby ochrony roślin w Polsce.

Utworzenie Działu Ochrony Roślin w INGW było na pewno konsekwencją, podejmowanych wcześniej na terenie zaborów przez pracowników polskiego pochodzenia, badań i działań w obszarze ochrony roślin, jak też rozumienia znaczenia ochrony roślin dla rozwoju produkcji rolniczej.

Celem niniejszego opracowania jest omówienie rozwoju ochrony roślin w Polsce po roku 1918 oraz przedstawienie w bardzo ograniczonym zakresie wcześniej podejmowanych działań i inicjatyw.

\section{Kartki $z$ historii / Some facts from the history}

Historia początków i rozwoju ochrony roślin w Polsce była przedmiotem licznych opracowań (Demby 1969; Gołębiowska 1978; Węgorek 1978; Stachowicz 2000; Lipa 2001; Pruszyński 2001, 2008; Matela 2011; Orlikowski i Lipa 2014; Anon 2018), a tutaj omówione zostaną jedynie najważniejsze wydarzenia, które w jej rozwoju odegrały kluczową rolę.

Rok 1780 - wydanie książki ks. Krzysztofa Kluka „Zwierząt domowych i dzikich, osobliwie krajowych, historii i naturalnej początki i gospodarstwo, potrzebnych i pożytecznych chowanie, rozmnażanie, chorób leczenie, dzikich łowienie, oswajanie i zażycie, szkodliwych zaś wygubienie”, w której w tomie IV „O owadzie i robakach” w rozdziale IV „O owadzie szkodliwym roślinom” autor opisał szkodniki roślin sadowniczych, ogrodniczych oraz upraw polowych, a także znane wtedy metody ochrony. Ksiądz Krzysztof Kluk jest przy tym pierwszym autorem książek rolniczych w Polsce, w których wprowadził do rolnictwa podstawy i wyniki badań naukowych. Druga połowa XVIII wieku była bowiem okresem, kiedy w rolnictwie m.in. rozpoczęto odchodzenie od trójpolówki i wprowadzanie zalecanego przez naukę płodozmianu.

Doceniając znaczenie ochrony roślin ks. Krzysztof Kluk zachęcał do jej stosowania i pisał: ,wielki jest zysk z rolnictwa, kiedy się przynajmniej, ile możliwości, uszkodzeniom zapobiega". Krytykował przy tym niski poziom polskiego rolnictwa pisząc: „Polska śpi na pośmiewisko mądrej Europy, skarży się na swe niedostatki, nie chce przecież dla własnego pożytku ziemi swojej hojniejszej przyczynić doskonałości”.
Trzeba będzie wielu lat, aby ten obraz polskiego rolnictwa zmienił się, $\mathrm{w}$ tym $\mathrm{w}$ wielu przypadkach $\mathrm{z}$ winy zaborców.

Rok 1816 - utworzenie w Marymoncie pod Warszawą Instytutu Agronomicznego - pierwszej na ziemiach polskich i jednej z pierwszych w Europie Wyższej Szkoły Rolniczej. Przeniesiony w 1862 r. do Puław po powstaniu styczniowym, zrusyfikowany i przekształcony w Instytut Politechniczny i Rolniczo-Leśny, w roku 1915 został ewakuowany do Rosji, a w opuszczonych pomieszczeniach za zgodą władz austriackich Polacy zorganizowali Instytut Naukowy Gospodarstwa Wiejskiego.

Rok 1836 - ukazuje się 12-tomowe dzieło „Gospodarstwo wiejskie” autorstwa Michała Oczapowskiego - Dyrektora Instytutu Agronomicznego, zwanego ojcem nowoczesnego rolnictwa polskiego. W IV tomie dzieła w rozdziale drugim zatytułowanym „O pielęgnowaniu roślin w czasie ich wzrostu, tudzież ochronie ich, począwszy od zasiewu aż do sprzętu”, Oczapowski użył terminów: „ochrona, choroby, robactwo szkodliwe".

Rok 1848 - Antoni Waga opublikował w czasopiśmie „Revue Zoologique et Applique” (Francja) wyniki swoich obserwacji nad masowym pojawem niezmiarki paskowanej (Chlorops pumilionis) w okolicach Warszawy, co można traktować jako wykonanie pierwszych, indywidualnych badań naukowych w Polsce.

Natomiast druga połowa XIX wieku przyniosła bardzo znaczny wzrost badań $\mathrm{w}$ zakresie ochrony roślin prowadzonych przez polskich uczonych. W dziedzinie fitopatologii za pioniera badań uznaje się prof. Edwarda Janczewskiego, kierownika Zakładu Botaniki Uniwersytetu Jagiellońskiego. Z jego Zakładu wyszli wybitni fitopatolodzy m.in. E. Namysłowski, K. Rouppert i K. Stecki. Znaczący wkład w rozwój fitopatologii w Polsce wniósł prof. Jan Brzeziński, którego badania dotyczyły głównie bakterioz drzew owocowych, a także J. Aleksandrowicz Dyrektor Ogrodu Botanicznego w Warszawie, który na zlecenie Towarzystwa Rolniczego w Warszawie przeprowadził badania zakończone opracowaniem broszury „Jakie są przyczyny tworzenia się śnieci i rdzy na pszenicy, jakimi środkami można się od niej uchronić". W badaniu chorób owadów duże zasługi położył światowej sławy botanik L. Cienkowski (Demby 1969; Orlikowski i Lipa 2014).

Rok 1856 - otwarcie Szkoły Rolniczej w Dublanach koło Lwowa, zwanej później Akademią Rolniczą.

Rok 1861 - książka Gustawa Belki „O owadach szkodliwych gospodarstwu wiejskiemu i sposobach ustrzeżenia się od nich lub zmniejszenia ich liczby" - pierwszy polski podręcznik z zakresu entomologii stosowanej.

Rok 1870 - rozpoczęcie działalności Wyższej Szkoły Rolniczej im. Haliny w Żabikowie koło Poznania. W konsekwencji restrykcyjnych decyzji władz pruskich, szkołę rozwiązano po pięciu latach.

Rok 1870 - Maksymilian Siła-Nowicki profesor Uniwersytetu Jagiellońskiego wydał opracowanie „O szkodach 
wyrządzanych w 1869 r. w plonach polnych przez zwierzęta szkodliwe", a w roku 1871 monografię o niezmiarce paskowanej (Ch. pumilionis). W ramach Komisji Fizjograficznej Towarzystwa Naukowego i Akademii Umiejętności w Krakowie, zainicjował systematyczną rejestrację występowania szkodników na terenie Galicji. Dążył do utworzenia urzędu i instytutu do spraw ochrony roślin i chociaż, pomimo pozytywnej decyzji miejscowych władz, nie udało się doprowadzić do realizacji tych zamierzeń, to działalność M. Siły-Nowickiego była jedną z pierwszych w Europie i na świecie i jest szeroko cytowana w literaturze z zakresu ochrony roślin.

Rok 1881 - książka Szczęsnego Kudelki - „Choroby roślin gospodarskich ich przyczyny i środki zaradcze” pierwszy polski podręcznik z zakresu fitopatologii.

Rok 1892 - Zygmunt Mokrzecki organizuje pierwszą w Rosji, w Symferopolu na Krymie, Stację Ochrony Roślin przed chorobami i szkodnikami, a także ustanawia stanowisko entomologa gubernialnego i Stację Doświadczalną. W roku 1922 wraca do Polski i obejmuje stanowisko kierownika Katedry Entomologii i Ochrony Lasu w Szkole Głównej Gospodarstwa Wiejskiego w Warszawie z siedzibą w Skierniewicach. Odegrał on ważną rolę w organizacji badań i pracy Towarzystw Naukowych w okresie międzywojennym w Polsce.

W badaniach dotyczących szkodników, obok już wymienionych prof. Maksymiliana Siły-Nowickiego i Zygmunta Mokrzyckiego, duży wkład wnieśli także prof. Antoni Karpiński pracujący w Instytucie w Nowej Aleksandrii (Puławach) oraz profesorowie S. Minkiewicz, J. Ruszkowski, J. Kinel, J. Noskiewicz i K. Simm, którzy swą działalność badawczą, dydaktyczną i organizacyjną kontynuowali w niepodległej Polsce.

Rok 1904 - przy Towarzystwie Ogrodniczym Warszawskim zostaje utworzona „Naukowa Pracownia Badań nad Ochroną Roślin” kierowana przez K. Kulwieć, przemianowana w roku 1912 na Stację Ochrony Roślin kierowaną przez prof. J. Trzebińskiego.

Utworzenie tej placówki o wybitnie praktycznym ukierunkowaniu było ważnym wydarzeniem w organizacji ochrony roślin na ziemiach polskich.

Rok 1910 - utworzenie Oddziału Ochrony Roślin przy Stacji Botaniczno-Rolniczej we Lwowie. Przyłączony tymczasowo do Katedry Rolnictwa Akademii Rolniczej w Dublanach, Oddział ten największy rozwój osiągnął w latach 1910-1912.

Omówiona aktywność nie byłaby pełna bez podania nazwisk pracowników naukowych zajmujących się ochroną roślin, a zatrudnionych na terenie zaboru rosyjskiego i austriackiego. Jako przykład wymienić tu należy omówioną wcześniej działalność profesora Zygmunta Mokrzyckiego, a także profesorów Józefa Trzebińskiego, Ludwika Garbowskiego, Jana Ruszkowskiego i Stanisława Minkiewicza. Profesorowie ci po odzyskaniu przez Polskę niepodległości niezwykle aktywnie uczestniczyli w organizacji prowadzenia badań i działaniach praktycznych w ochronie roślin na terenie kraju.

O udziale polskich pracowników naukowych w tworzeniu i rozwoju entomologii stosowanej szerzej pisali Pruszyński i Boczek (2011), a w opracowaniu biologicznej metody zwalczania szarka komośnika na terenie obecnej Ukrainy duże zasługi wnieśli Danysz i Wize (1901).

Lata rozbiorów były też czasem różnicowania poziomu polskiego rolnictwa uzależnionego od politycznych i gospodarczych decyzji zaborców (Krasowicz 2002).

Niezależnie jednak od tych uwarunkowań, duży wpływ na rozwój rolnictwa miały inicjatywy miejscowej ludności polskiej. W zaborze pruskim, w którym społeczeństwo polskie poddawane było bardzo silnemu procesowi germanizacji, obronę narodowości postrzegano w dążeniu do podnoszenia kultury rolnej we wszystkich grupach rolników. Działalność tę określano mianem „,pracy organicznej” lub „pracy od podstaw”. Dlatego też w odróżnieniu od dwu pozostałych zaborów, postęp w rolnictwie dotyczył nie tylko ziemiaństwa czy gospodarstw o większym areale, ale wszystkich rolników. Ten olbrzymi wysiłek i jego efekty najbardziej są widoczne w przedstawionych przez Krasowicza (2002) plonach podstawowych upraw rolniczych na terenie Polski przed wybuchem I wojny światowej (tab. 1). Na pewno nie bez znaczenia był fakt, że tereny zaboru pruskiego sąsiadowały z krajami Europy zachodniej, w których przemiany w rolnictwie były zapoczątkowane i realizowane wcześniej, szczególnie w porównaniu do zaboru rosyjskiego.

\section{Lata 1918-1939, Organizacja badań i nauczania / Years 1918-1939, Organization of the reserch and education}

Odzyskaniu niepodległości przez nasz kraj towarzyszyło wiele decyzji, których celem było powołanie i utworzenie instytucji i urzędów zabezpieczających nie tylko funkcjonowanie państwa polskiego, ale także zagwarantowanie rozwoju szkolnictwa na wszystkich jego poziomach, nauki, a także produkcji zarówno przemysłowej, jak i rolniczej. Zapadły też wtedy ważne decyzje dotyczące badań i działań praktycznych. W obszarze ochrony roślin za najważniejsze należy uznać utworzenie 1 stycznia 1918 r. w INGW w Puławach Działu Ochrony Roślin. W skład Działu wchodziły pododdziały: pasożytów roślinnych, pasożytów zwierzęcych oraz badania chwastów. Kierownikiem Działu został wybitny fitopatolog prof. dr J. Trzebiński, który od roku 1912 kierował utworzoną w Warszawie Stacją Ochrony Roślin. W roku 1919 w Bydgoszczy utworzono związany organizacyjnie z Działem w Puławach, Wydział Chorób Roślin, którym kierował prof. dr L. Garbowski. 
Ustawą sejmową z 20 października 1921 r. INGW został przemianowany na Państwowy Instytut Naukowy Gospodarstwa Wiejskiego (PINGW), a Oddział Ochrony Roślin na Wydział Ochrony Roślin.

Po przeniesieniu się w 1924 r. prof. J. Trzebińskiego do Wilna, stanowisko kierownika Wydziału powierzono prof. S. Minkiewiczowi. W wyniku kolejnych zmian w strukturze PINGW w 1937 r. utworzony został Wydział Chorób i Szkodników Roślin z następującą strukturą organizacyjną: Dział Chorób w Bydgoszczy i Puławach - kierownik prof. L. Garbowski, Dział Entomologiczny w Puławach z pracowniami w Bydgoszczy i we Lwowie - kierownik prof. S. Minkiewicz oraz Dział Ochrony Roślin utworzony z przeniesionych do Puław pracowników zlikwidowanej Stacji Ochrony Roślin przy Warszawskim Towarzystwie Ogrodniczym - kierownik prof. J. Ruszkowski.

Zarówno dla badań naukowych, jak i, a może przede wszystkim, przygotowania specjalistów z zakresu ochrony roślin bardzo ważne znaczenie miało utworzenie Szkoły Głównej Gospodarstwa Wiejskiego (SGGW) w Warszawie oraz Wydziału Rolniczo-Leśnego na Uniwersytecie Poznańskim.

W ramach SGGW, w latach 1918-1922 w Skierniewicach utworzono pierwsze w Polsce jednostki dydaktyczno-naukowe: Zakład Patologii Roślin, którym w roku 1921 kierował prof. L. Garbowski, a w następnych latach prof. W. Siemiaszko oraz Zakład Ochrony Lasu i Entomologii, którym kierował prof. Z. Mokrzecki.

W Poznaniu w roku 1919, w ramach Wydziału Rolniczo-Leśnego Uniwersytetu Poznańskiego utworzono Katedrę Zoologii i Entomologii, którą kierował prof. Ludwik Sitowski oraz Katedrę Botaniki Ogólnej i Fitopatologii, której kierownikiem był prof. Bolesław Namysłowski. W 1924 r. w ramach Studium Rolniczego i Wydziału Matematycznego Przyrodniczego Uniwersytetu Wileńskiego został utworzony Zakład Fitopatologii, którym kierował prof. J. Trzebiński.
$\mathrm{W}$ różnym zakresie badania, wykłady i ćwiczenia dotyczące ochrony roślin były prowadzone na Uniwersytecie Jagiellońskim i Wileńskim oraz Akademii Rolniczej w Dublanach.

Ważną rolę w przygotowaniu specjalistów z zakresu ochrony roślin odgrywały - utworzona w roku 1926 w Poznaniu trzyletnia Szkoła Ogrodnicza typu średnio-wyższego oraz Państwowa Wyższa Szkoła Gospodarstwa Wiejskiego w Cieszynie.

\section{Ukierunkowanie badań / Research subjects}

Prowadzone w okresie międzywojennym badania, prof. Władysław Węgorek ocenia jako skromne, ale bardzo wartościowe, które miały duże znaczenie poznawcze i praktyczne. W pierwszym rzędzie należy wymienić badania i stałe obserwacje nad występowaniem i nasileniem występowania chorób i szkodników roślin uprawnych.

Należy pamiętać, że niepodległa Polska powstała z połączenia terenów będących przez prawie 130 lat pod okupacją trzech różnych zaborców i opracowanie stanu fitosanitarnego dla całego kraju było konieczne (Węgorek 1978).

Niezależnie od tych badań prowadzono szczegółowe obserwacje nad biologią, ekologią i systematyką występujących organizmów szkodliwych, a dobrym przykładem jest tu monografia autorstwa Karola Zalewskiego, wybitnego polskiego fitopatologa, „Gatunki grupy Penicillium znalezione w Polsce” wydana w Krakowie w 1927 roku.

Gołębiowska (1978) ocenia, że publikowane w okresie międzywojennym prace były na bardzo wysokim poziomie $\mathrm{i}$ wiele $\mathrm{z}$ poznanych wtedy zagadnień nie straciło nic ze swej aktualności do czasów obecnych. Natomiast

Tabela 1. Plony zbóż i ziemniaków na ziemiach polskich przed I wojną światową (średnie za okres pięcioletni) według Krasowicza (2002)

Table 1. Yield of the cereals and potatoss in different regions of Poland before I world war according Krasowicz (2002)

\begin{tabular}{|c|c|c|c|c|c|}
\hline \multirow{2}{*}{$\begin{array}{l}\text { Ziemiopłody } \\
\text { Crops }\end{array}$} & \multirow{2}{*}{$\begin{array}{l}\text { Wielkopolskie } \\
\text { Region } \\
\text { Wielkopolskie }\end{array}$} & \multicolumn{2}{|c|}{$\begin{array}{c}\text { Zabór rosyjski } \\
\text { Russion annexaction }\end{array}$} & \multirow{2}{*}{$\begin{array}{c}\text { Zabór austriacki } \\
\text { Austria } \\
\text { annexation }\end{array}$} & \multirow{2}{*}{$\begin{array}{c}\text { Średnia dla } \\
\text { wszystkich ziem } \\
\text { Average for all } \\
\text { Poland terytory }\end{array}$} \\
\hline & & $\begin{array}{c}\text { woj. centralne } \\
\text { central } \\
\text { voivodeship }\end{array}$ & $\begin{array}{c}\text { woj. wschodnie } \\
\text { east } \\
\text { voivodeship }\end{array}$ & & \\
\hline $\begin{array}{l}\text { Pszenica } \\
\text { Wheat }\end{array}$ & 20,8 & 12,3 & 9,8 & 11,7 & 12,4 \\
\hline $\begin{array}{l}\text { Żyto } \\
\text { Ray }\end{array}$ & 17,2 & 10,5 & 7,8 & 11,2 & 11,2 \\
\hline $\begin{array}{l}\text { Owies } \\
\text { Out }\end{array}$ & 18,1 & 9,5 & 8,0 & 10,7 & 10,2 \\
\hline $\begin{array}{l}\text { Jęczmień } \\
\text { Barley }\end{array}$ & 20,2 & 11,7 & 8,0 & 11,2 & 11,8 \\
\hline $\begin{array}{l}\text { Ziemniaki } \\
\text { Potato }\end{array}$ & 144,3 & 94,4 & 67,4 & 111,3 & 103,0 \\
\hline
\end{tabular}


prowadzone obserwacje nad pojawem, zasięgiem i nasileniem występowania chorób, szkodników i ważniejszych chwastów stanowią cenne informacje pozwalające na śledzenie zmian dotyczących znaczenia gospodarczego i pojawów organizmów szkodliwych.

\section{Towarzystwa naukowe i działalność wydawnicza I Scientific and professional societes and publishing activity}

Pracownicy naukowi ochrony roślin przejawiali dużą aktywność i z niemałym zaangażowaniem dążyli do integracji środowiska oraz tworzenia wydawnictw, w których prezentowano wyniki badań naukowych i obserwacji, a także materiałów do wykorzystania przez pracowników służby ochrony roślin i praktyków.

Już w styczniu 1923 r. miał miejsce pierwszy Zjazd Fitopatologów i Entomologów Polski, w czasie obrad którego uchwalono m.in. wydawanie czasopisma poświęconego ochronie roślin.

Następne 7 zjazdów i konferencji zorganizowano w latach 1927-1937 (Orlikowski i Lipa 2014).

W tym samym czasie powołany został we Lwowie Polski Związek Entomologiczny. Nazwę Związku na Polskie Towarzystwo Entomologiczne przyjęto w 1965 r., a w 1934 r. przy Związku powstała Sekcja Entomologii Stosowanej.

W 1924 r. przy Ministerstwie Rolnictwa i Dóbr Państwowych powstał Komitet Ochrony Roślin, który podjął wydawanie czasopisma „Choroby i Szkodniki Roślin”. Obok wydawania czasopisma do zadań Komitetu należało szerokie informowanie producentów rolnych oraz służby ochrony roślin o ustawodawstwie, instytucjach zajmujących się ochroną roślin oraz danych o zdrowotności upraw. Praca Komitetu Ochrony Roślin została szczegółowo omówiona w opracowaniu Orlikowskiego i Lipy (2014).

29 listopada 1931 r. miało miejsce zebranie organizacyjne Polskiego Towarzystwa Ochrony Roślin. W zebraniu udział wzięła duża grupa pracowników naukowych oraz Stacji Ochrony Roślin, a pierwszym Przewodniczącym Towarzystwa został wybrany prof. Z. Mokrzecki. Towarzystwo podjęło wydawanie czasopisma „Choroby Roślin".

Warto również odnotować powstanie w 1925 r. Komisji Ochrony Roślin przy Wydziale Doświadczalno-Naukowym Centralnego Towarzystwa Rolniczego, przekształconej następnie w Sekcję Ochrony Roślin Związku Rolniczych Zakładów Doświadczalnych Rzeczypospolitej Polskiej.

Natomiast w roku 1927 w czasie obrad Konferencji Fitopatologów i Entomologów postanowiono utworzyć „Związek Pracowników Naukowych w Dziedzinie Ochrony Roślin” oraz podjąć wydawanie czasopisma „Choroby i Szkodniki Roślin” (Lipa J.J. - informacja ustna).

\section{Rozwój doradztwa i służby ochrony roślin / Deve- lopment of advisory and plant protection service}

Bardzo ważną rolę w rozwoju ochrony roślin w Polsce w okresie międzywojennym odegrały tworzone na terenie całego kraju Stacje Ochrony Roślin. Najczęściej Stacje działały w ramach Izb Rolniczych wchodząc w okresie późniejszym w skład oficjalnych zakładów fitosanitarnych w Polsce.

Do zadań Stacji należały m.in.:

- diagnostyka chorób i szkodników oraz organizowanie akcji zwalczania gatunków objętych rozporządzeniami Ministra Rolnictwa,

- rejestracja pojawu i występowania organizmów szkodliwych,

- prace oświatowe, upowszechnieniowe i szkolenia,

- doświadczalnictwo polowe.

Pisząc o zadaniach realizowanych przez Stacje Ochrony Roślin należy brać pod uwagę trudności, jakie wynikały z wielowiekowej tradycji błędnego tłumaczenia pojawów organizmów szkodliwych oraz braku wykonywania przez producentów zabiegów ochrony roślin.

Kierownik Wielkopolskiej Stacji Ochrony Roślin A. Kuryłło w sprawozdaniu z działalności Stacji w roku 1926 (Kuryłł 1927) napisał, że parę przesyłek nadeszło od małorolnych gospodarzy, którzy do niedawna przyjmowali choroby roślin jako ,dopust Boży, któremu przeciwdziałać nie tylko, że nie wypadało, ale i na nic by się nie zdało". Natomiast w sprawozdaniu za rok $1927 \mathrm{Ku}-$ ryłł (1928) napisał: „Niech i w Polsce nareszcie zapanuje ta już dawno zagranicą zrozumiana zasada, że troska o stan zdrowotności kultur roślinnych jest tak samo ważnym zadaniem rolnika jak siew, uprawa czy nawożenie".

Duży udział mieli pracownicy Stacji w zbiorze informacji dotyczących pojawów i nasilenia występowania ważniejszych chorób i szkodników roślin uzyskiwanych na podstawie analizy nadsyłanych do Stacji prób, obserwacji własnych oraz pracujących społecznie korespondentów zorganizowanych w Komitetach Ochrony Roślin - Powiatowych, Gminnych, Miejskich i Gromadzkich. W Wielkopolsce liczba korespondentów wynosiła w 1937 r. 417 osób, a liczba nadesłanych sprawozdań przekraczała 1000 w ciągu jednego roku (Pruszyński 2008). Zebrane informacje były wykorzystywane w pracy Stacji, a także przesyłane do Wydziału Chorób Roślin PINGW w Bydgoszczy oraz Dyrekcji Instytutu w Puławach stając się podstawą zbiorczych opracowań o stanie fitosanitarnym upraw w Polsce.

Stacje Ochrony Roślin odpowiedzialne były za prowadzenie obserwacji nad występowaniem i zwalczaniem gatunków szkodliwych określonych decyzjami Ministra Rolnictwa lub władz lokalnych. Dotyczyło to raka ziemniaka (Synchytrium endobioticum), bawełnicy korówki (Eriosoma lanigerum), płaszczyńca burakowego (Piesma quadrata), 
chwościka burakowego (Cercospora beticola) czy zwalczania ostów (Cirsium sp.). O zakresie prowadzonych prac w odniesieniu do bawełnicy korówki mogą świadczyć dane z Wielkopolski z roku 1934, w której przeprowadzono lustracje na obecność tego szkodnika w 1380 miejscowościach, $10236 \mathrm{w}$ sadach i $231 \mathrm{~km}$ alei przydrożnych. Stwierdzono 1334 ogniska szkodnika, które zlikwidowano. W walce z rakiem ziemniaczanym wiosną 1929 r. wprowadzono w Wielkopolsce obowiązek obsadzania pól, gdzie występowała choroba, odmianami ziemniaka rakoodpornymi dostarczając na zagrożone tereny 14 335,72 q sadzeniaków (Pruszyński 2008).

Kolejnymi formami działalności Stacji Ochrony Roślin były: organizacja szkoleń, demonstracji, zakładanie doświadczeń polowych i wazonowych, prowadzenie sekcji zwalczania szkodników, a także działalność wydawnicza prowadzona często we współpracy ze Związkami Plantatorów czy przemysłem.

Jeżeli do tego co napisano, dodać dobre przygotowanie zawodowe pracowników Stacji Ochrony Roślin i ich olbrzymie zaangażowanie $w$ realizację stawianych zadan, to z pełnym przekonaniem można mówić o znaczącym i ważnym udziale pracowników Stacji w rozwój ochrony roślin w Polsce w tamtych latach.

\section{Ustawodawstwo z zakresu ochrony roślin / Acts and directives concerning plant protection}

Jak napisano wcześniej, odzyskanie przez Polskę niepodległości było podstawą do utworzenia państwa polskiego, w skład którego weszły obszary znajdujące się przez blisko 130 lat przed panowaniem trzech różnych zaborców. Bardzo ważnym stało się zatem przygotowanie i uchwalenie polskiej ustawy o ochronie roślin wprowadzającej ujednolicone przepisy obowiązujące w całym kraju przy jednoczesnej utracie mocy przepisów wcześniejszych. Funkcję tę spełniło wydane 19 listopada 1927 roku Rozporządzenie Prezydenta Rzeczypospolitej Polskiej o zwalczaniu chorób roślin oraz o tępieniu chwastów i szkodników (Dz. U. R.P. z dnia 7 XII 1927 r. Nr 108, poz. 922).

Uchwalone w 1927 roku Rozporządzenie zostało zastąpione „Ustawą z dnia 16 marca 1937 roku o zmianie Rozporządzenia Prezydenta Rzeczypospolitej z dnia 19 listopada 1927 r. o zwalczaniu chorób roślin oraz o tępieniu chwastów i szkodników roślin" (Dz. U. 1937 Nr 21, poz. 131) i zapisy tej ustawy obowiązywały w Polsce do czasu wybuchu II wojny światowej.

Niezależnie od dwóch wymienionych w okresie międzywojennym, wydano w Polsce 19 innych aktów prawnych dotyczących ochrony roślin (17 rozporządzeń, 1 ustawę i obwieszczenie) (Matyjaszczyk 2011). W większości były one poświęcone obowiązkowi zwalczania najgroźniejszych chorób i szkodników: korówki wełnistej (Erioroma larigerum Hausm.), płaszczyńca burakowego (Piesma quadrata
Fieb.), ostów, raka ziemniaczanego (Synchytrium endobioticum), berberysu i gryzoni polnych.

Jest charakterystyczne, że żaden z uchwalonych w tamtym okresie aktów prawnych nie podniósł problematyki chemicznych środków ochrony roślin, a pierwsze przepisy dotyczące zgód na wprowadzenie środków do stosowania były zamieszczone w tekstach Uchwał i Rozporządzeń innych Ministerstw i organów państwowych. Rozporządzenie zawierało cztery rozdziały, z których w pierwszym zatytułowanym „Postanowienia ogólne” zostały podane podstawowe definicje, omówione metody zwalczania oraz regulacje dotyczące zasad finansowania kosztów związanych z obowiązkowym zwalczaniem organizmów szkodliwych, a także pojęcia i zasady dotyczące kwarantanny.

Rozdział drugi był poświęcony organizacji nadzoru nad ochroną roślin oraz zobowiązywał PINGW i powoływane przez Ministra Rolnictwa instytucje do udzielania ekspertyz i opiniowania aktów prawnych. Rozdział trzeci zawierał przepisy karne na wypadek nieprzestrzegania ustalonych Rozporządzeniem postanowień oraz łącznie z treścią rozdziału czwartego informował o wycofaniu przepisów obowiązujących wcześniej w poszczególnych zaborach.

Bardzo ważny dla powstania Rozporządzenia był udział polskich fitopatologów i entomologów, którzy na Konferencji w 1923 roku przygotowali i uchwalili projekt polskiej ustawy ochrony zawierający m.in. następujące zapisy (Lipa J.J. - materiały do referatu):

Art. I. Każdy właściciel, posiadacz, dzierżawca lub użytkownik gruntu obowiązany jest zwalczać, na gruntach będących w jego posiadaniu, w dzierżawie lub pod jego zarządem, niebezpieczne szkodniki zwierzęce, choroby roślin i chwasty.

Art. II. Każdy właściciel, posiadacz, dzierżawca i użytkownik gruntu, obowiązany jest meldować wójtom gmin o pojawieniu się niebezpiecznych szkodników i chorób roślin na gruntach będących $\mathrm{w}$ jego posiadaniu, dzierżawie lub pod jego zarządem.

Art. III. Na wniosek Izb Rolniczych, a tam gdzie ich nie ma, na wniosek samorządów ogólnych, organizacji społeczno-rolniczych i instytucji ochrony roślin, Minister Rolnictwa i Dóbr Państwowych ma prawo zarządzić wykonanie niniejszej ustawy w miejscowościach nieobjętych jej działaniem.

Art. IV. Minister Rolnictwa i Dóbr Państwowych w osobnych rozporządzeniach wymienia niebezpieczne szkodniki zwierzęce, choroby roślin i chwasty i podaje sposoby walki $\mathrm{z}$ nimi.

Art. V. Osoby upoważnione przez Ministra Rolnictwa i Dóbr Państwowych mają prawo dokonywania oględzin wszelkich upraw roślin zarówno na otwartym powietrzu, jak pod szkłem i w innych miejscach.

Art. VI. Minister Rolnictwa i Dóbr Państwowych w porozumieniu z Ministrem Skarbu i Ministrem Przemysłu i Handlu ma prawo zabronić, względnie ograniczyć przewóz roślin i ich części z zagranicy, o ile wwóz grozi zawlecze- 
niem do Rzeczypospolitej Polskiej, groźnych szkodników i chorób roślin.

Art. VII. Wszelkie przesyłki przychodzące z zagranicy, zawierające rośliny lub ich części, mogą być rewidowane na komorach celnych przez upoważnionych przez Ministerstwo Rolnictwa i Dóbr Państwowych rzeczoznawców.

Przedstawiony projekt wskazuje na głęboką znajomość zagadnień i potrzeb wymaganych dla prawidłowego realizowania zadań w zakresie ochrony upraw na terenie kraju.

\section{Rozwój metod ochrony i ich praktyczne wykorzy- stanie / Development on plant protection methods and their application in practice}

W Polsce międzywojennej, w latach 1918-1939, przy potrzebie znacznego doszkalania producentów rolnych i przekonania o konieczności ochrony upraw przed organizmami szkodliwymi, wdrożono i wykorzystano wszystkie dostępne metody ochrony roślin. Bardzo ważne znaczenie odgrywała metoda mechaniczna $\mathrm{w}$ połączeniu $\mathrm{z}$ metodą fizyczną i zabiegami kwarantannowymi. Zwalczanie organizmów, podlegających obowiązkowi zwalczania, polegało w większości przypadków na szczegółowych lustracjach upraw i likwidowaniu (fizycznie) znajdowanych ognisk organizmu szkodliwego. Podobnie postępowano likwidując rośliny ostu oraz krzewy berberysu. Liczne były akcje zbierania chrząszczy chrabąszczy w czasie ich letnich wylotów, a do pomocy organizowano młodzież szkolną.

Metodę hodowlaną szeroko wykorzystywano w walce $\mathrm{z}$ rakiem ziemniaczanym, uprawiając na terenach zagrożonych odmiany ziemniaka odporne na tą chorobę. Przykładem wykorzystania metody biologicznej było sprowadzenie do Polski na początku lat 30. ubiegłego wieku, pasożyta bawełnicy korówki - ośca korówkowego (Aphelinus mali Hald.). Sprowadzenie tego pasożyta i jego rozmnożenie pozwoliło na praktycznie zupełne zlikwidowanie zagrożenia ze strony tego groźnego szkodnika szkółek drzew owocowych i sadów.

Do działań w ramach metody biologicznej należy zaliczyć prowadzony na terenie Polski zbiór pasożytów i ich wysyłkę do Stanów Zjednoczonych celem ograniczenia liczebności gatunków szkodników zawleczonych do tego kraju z Europy. Jakkolwiek brak jest przykładów wykorzystania zbieranych i hodowanych pasożytów w polskiej ochronie roślin, to jednak badania te pozwalały na szczegółowe poznanie wrogów naturalnych badanych szkodników.

Równolegle do działań podejmowanych w innych krajach, w Polsce już w XIX wieku rozpoczęto produkcję chemicznych środków ochrony roślin oraz aparatury do ich stosowania. W latach międzywojennych głównymi dostawcami środków ochrony roślin były firmy „Azot” w Jaworznie oraz „Uniwersum” w Poznaniu. W Warszawie działała firma „Siessa”, a aparaturę ochrony roślin produkowano w „Azot” - Jaworzno i „Ciszewski” - Leszno.
Matyjaszczyk (2011) podaje, że fabryka „Uniwersum” w roku 1929 oferowała w sprzedaży przynajmniej 23 preparaty, a spółka „Azot” w roku 1937 aż 25 środków. Obie firmy prowadziły też sprzedaż aparatury ochrony roślin opryskiwaczy i opylaczy, a także okularów ochronnych. Oferowane środki ochrony roślin, przeznaczone były do zwalczania szkodników owadzich (związki arsenu i nikotyny), gryzoni (fosforek cynku), chorób roślin (ciecz bordowska, ciecz kalifornijska, karbolina sadownicza, maści sadownicze) oraz repelenty do odstraszania zwierzyny łownej. W wydawanych przez producentów katalogach można znaleźć ostrzeżenie przed zakupem i stosowaniem środków pochodzących od anonimowych producentów, a także zalecenie zakupu produktów krajowych.

Wyrób i sprzedaż chemicznych środków przeznaczonych do walki ze szczurami, mszycami, owadami i pasożytami zwierzęcymi, odbył się na podstawie Zasadniczej Ustawy Sanitarnej z dnia 19 lipca 1919 r. oraz Rozporządzenia Ministra Spraw Wewnętrznych i Ministra Przemysłu i Handlu z dnia 16 listopada 1924 r. Wymienione akty prawne ustalały system wydawania zezwoleń na wyrób i wprowadzenie środków do handlu, wymagania dotyczące treści etykiety i oznakowania, a także warunki przechowywania i sprzedaży. Zezwolenia na środki przeznaczone do zwalczania pasożytów zwierzęcych udzielano w porozumieniu z Ministrem Rolnictwa i Dóbr Państwowych.

Jednostką odpowiedzialną za rejestrację była Generalna Dyrekcja Służby Zdrowia Ministerstwa Spraw Wewnętrznych. Na podstawie Rozporządzenia z listopada 1924 roku dokonano wznowienia zezwoleń wydanych wcześniej na podstawie przepisów obowiązujących w niektórych zaborach i działania te można uznać za początek tworzenia systemu dopuszczenia środków ochrony roślin do obrotu i stosowania na terenie Polski.

Przy ograniczonej dostępności bezpośrednich metod zwalczania, a także w oparciu o wiedzę o środowisku i zachodzących w nim procesach, w opracowanych w tamtym okresie programach ochrony, dominowały zalecenia niezwykle zbliżone i wręcz pokrywające się z obecnymi zaleceniami integrowanej ochrony roślin.

Przykładem może tu być fragment wstępu opracowanego przez dr J. Ruszkowskiego w 1927 r. komunikatu ,Walka ze szkodnikami sadów wczesną wiosną przed pękaniem pączków zimowych" (Ruszkowski 1927):

„Zwalczanie ważniejszych chorób i szkodników roślin zwykle się wielokrotnie opłaca pod warunkiem, że ogrodnik:

1. wie z jakim szkodnikiem lub chorobą zamierza walczyć;

2. czyni wszystko, co w danym przypadku należy w odpowiednim czasie i dokładnie;

3. nie trzyma się rutyny, lecz znając zwyczaje swoich wrogów, przystosowuje swe czynności do niedających się ująć w szablon czynników wywierających wpływ w danym razie - jak właściwości danego klimatu, gleby, odmiany i stanu zdrowotnego roślin, pogody, specyficznych warunków gospodarczych itd., itd." 


\section{Lata II wojny światowej (1939-1944) / Years of the secend world war (1939-1944)}

II wojna światowa nie tylko, że wstrzymała rozwój, ale doprowadziła też do bardzo poważnych strat w polskiej ochronie roślin. PINGW w Puławach został przemianowany na Rolniczy Zakład Badawczy Generalnego Gubernatorstwa w ramach, którego utworzono m.in. Instytut Ochrony Roślin, jednakże kierownictwo Instytutu stanowili pracownicy niemieccy. Z drugiej jednak strony w Instytucie Ochrony Roślin znalazło zatrudnienie wielu pracowników naukowych, również z innych ośrodków, co pozwoliło im przeżyć okres okupacji (Gołębiowska 1978; Lipa 2001). Okupanci zlikwidowali placówki w Bydgoszczy, Poznaniu, Lwowie i Wilnie. Zmarł prof. S. Minkiewicz, a wielu pracowników w związku z działalnością konspiracyjną musiało chronić się za granicą, np. dr E. Judenko. Dla praktyki ochrony roślin był to okres zaniedbań w prowadzeniu zwalczania chorób, szkodników, gryzoni i szkodników glebowych, co doprowadziło w wielu przypadkach do ich masowych pojawów.

\section{Uwagi końcowe / Final conclusions}

Omawiając rozwój ochrony roślin w Polsce po roku 1918 należy podkreślić trzy bardzo istotne fakty. Pierwszy, to znaczne trudności wynikające $\mathrm{z}$ bardzo różnego poziomu rolnictwa na terenach będących pod administracją trzech różnych zaborców i różne przygotowanie rolników, z których część nie miała, nie tylko wiedzy, ale i przekonania do potrzeby prowadzenia zabiegów ochronnych roślin.

Drugi, bardzo ważny moment, to polscy specjaliści z zakresu ochrony roślin pracujący na terenie zaborów rosyjskiego i austriackiego, którzy natychmiast po odzyskaniu przez Polskę niepodległości, przystąpili do organizacji badań i wdrażania zabiegów ochrony roślin na terenie kraju.

Wreszcie, trzeci moment, to olbrzymie zaangażowanie pracowników, nie tylko Instytutów, uczelni czy Stacji Ochrony Roślin, ale także innych instytucji i osób prywatnych w prowadzeniu badań, obserwacji i zabiegów ochrony roślin. To dzięki tym uwarunkowaniom, ochrona roślin rozwijała się w Polsce w okresie przed II wojną światową zgodnie ze światowym postępem w tej dziedzinie rolnictwa, tworząc dobre podstawy do dynamicznego rozwoju po roku 1945.

\section{Literatura / References}

Anon 2018. 100 lat niepodległej polski. PIORIN z tradycją w przyszłość. 100 lat ochrony roślin i nasiennictwa w Polsce. Graden Poligrafia Grażyna Lenkiewicz, Warszawa, 102 ss.

Danysz J., Wize K. 1901. O użyciu muskardyn w walce z komornikiem buraczanym (Cleonus punctriventris). Odbitka z Gazety Cukrowniczej, $17 \mathrm{ss}$.

Demby W.M. 1969. Zarys historyczny ochrony roślin w Polsce. Postępy Nauk Rolniczych 1 (115): 109-132.

Gołębiowska Z. 1978. Od Marymontu do Poznania droga polskiej nauki ochrony roślin. [From Marymont to Poznań - the way of polish plant protection science]. Materiały XVIII Sesji Naukowej Instytutu Ochrony Roślin: 13-24.

Krasowicz S. 2002. Produkcja roślinna na ziemiach polskich w XIX i XX wieku - rys historyczny. Pamiętnik Puławski, Zeszyt Specjalny 130 (2): 11-31.

Kuryłło A. 1927. Choroby i szkodniki roślin uprawnych w Wielkopolsce w roku 1926. Wydawnictwo Wielkopolskiej Izby Rolniczej, Poznań, 31 ss.

Kuryłło A. 1928. Choroby i szkodniki roślin uprawnych w Wielkopolsce w roku 1927. Wydawnictwo Wielkopolskiej Izby Rolniczej, 20 ss.

Lipa J.J. 2001. Krótka historia ochrony roślin w Polsce w latach 1836-1950. [Short history of plant protection in Poland 1836-1950]. Progress in Plant Protection/Postępy w Ochronie Roślin 41 (1): 32-38.

Matela D. 2011. Historia ochrony roślin w Polsce. s. 73-81. W: „Profesor Władysław Węgorek życie i dzieła”. Muzeum Narodowe Rolnictwa i Przemysłu Rolno-Spożywczego, Szreniawa, Poznań.

Matyjaszczyk E. 2011. Analiza zmian ustawodawstwa z zakresu ochrony roślin pod kątem bezpieczeństwa żywności, ludzi i środowiska. Rozprawy Naukowe Instytutu Ochrony Roślin - Państwowego Instytutu Badawczego, Zeszyt 25, 130 ss.

Orlikowski L.B., Lipa J.J. 2014. Komitety Ochrony Roślin i ich rola w rozwoju ochrony roślin oraz integracji polskiego środowiska naukowego w latach 1924-2013. Instytut Ogrodnictwa, Skierniewice, 155 ss.

Pruszyński S. 2001. 50 lat Instytutu Ochrony Roślin w Poznaniu. [50 years anniversary of the Institute of Plant Protection in Poznań]. Progress in Plant Protection/Postępy w Ochronie Roślin 41 (1): 18-31.

Pruszyński S. 2008. Ochrona roślin rolniczych w Wielkopolsce w XX wieku. Rocznik Muzeum Narodowego Rolnictwa i Przemysłu Rolno-Spożywczego w Szreniawie 8 (5): 292-358.

Pruszyński S., Boczek J. 2011. Entomologia stosowana i jej twórcy w ochronie roślin w Polsce. Instytut Ochrony Roślin, P.J.B. Poznań, 44 ss.

Ruszkowski J. 1927. Walka ze szkodnikami sadów wczesną wiosną przed pękaniem pączków zimowych. Komunikat Pracowni Ochrony Roślin Szkoły Ogrodniczej, Poznań.

Stachowicz T. 2000. Historia służby ochrony roślin oraz obecne miejsce Inspekcji Ochrony Roślin w upowszechnianiu postępu i doradztwie. [The history of the plant protection service in Poland and actual role of the plant protection inspection in the dissemination of progress and extension tasks]. Progress in Plant Protection/Postępy w Ochronie Roślin 40 (1): 308-314.

Węgorek W. 1978. Ewolucja problematyki naukowej ochrony roślin na przestrzeni ubiegłych 60 lat. [Development of scientific plant protection problems within the compass of last 60 years]. Materiały XVIII Sesji Naukowej Instytutu Ochrony Roślin: 25-37. 